\title{
PRAYER, ORACLE AND THEOPHANY: THE BOOK OF HABAKKUK
}

\author{
Michael E.W. Thompson
}

\begin{abstract}
Summary
Habakkuk comprises laments, prophetic and woe oracles, and psalm (prayer), but there is progression of thought. In this book, a theological problem is stated and resolved. The different forms are used in purposeful and judicious ways. It is argued that there is one author, something of an eclectic who borrowed from wisdom and Isaianic traditions, in particular interpreting the latter and anticipating aspects of Isaiah 40-55. The theme of the book is theolicy. This is resolved in the psalm of chapter 3, through the language of prayer. Half the book is expressed in the language of prayer, making it unique among the prophetic books.
\end{abstract}

The book of Habakkuk comprises laments, prophetic oracles, a collection of woe oracles and a psalm, the last containing a petition, description of a theophany and a concluding expression of confidence. R.P. Carroll says: 'As a ragbag of traditional elements held together by vision and prayer Habakkuk illustrates the way prophetic books have been put together in an apparently slapdash fashion'.1

This contribution questions the appropriateness in this context of the words 'ragbag' and 'apparently slapdash', and suggests a rather different assessment of the book. First, the various units that make up the book are considered, with close attention being given to the particular literary forms used in each. Appropriate attention is also given to the many notorious exegetical problems encountered in the book. In a second major section the eclectic nature of the book and the tradition in which it seems to stand is considered. In the third place the principal theological concern of the work is laid bare, and suggestions are made as to why this is handled in the manner that renders the book unique among the prophetical texts in the Old Testament.

1.R.P. Carroll, 'Habakkuk', in R.J. Coggins \& J.L. Houlden (eds.), A Dictionary of Biblical Interpretation, (London, SCM 1990) 269. 


\section{Prayers, Oracles and Theophany}

\section{a. Habakkuk 1:1}

The book begins with a title that employs the word maśsaa', 'burden'. Apart from its general usage in the Old Testament for 'burden' this word finds its most consistent employment in the oracles against the nations in Isaiah 13-23. We should also note its usage in Nahum, a prophecy dominated by a word against a foreign nation. Perhaps we are intended to understand that a concern in Habakkuk is with a word of judgment against a foreign nation. We also note that in this title there is an absence of any dating formula.

\section{b. Habakkuk 1:2-4}

Now follows a prayer, to be more precise a complaint. This is uttered, let us assume for the time being, by the prophet Habakkuk, and it is on behalf of his people. In psalm study this type of complaint is called a communal lament: the present one is concerned with the fact that Yahweh appears neither to hear the prophet nor to act so as to save his people from their troubles (2). Habakkuk 1:2-4 typically follows the style and form of a communal lament psalm: there is the opening 'How long, Yahweh?' (cf. Ps. 13:2 [EVV 13:1]; 74:10; 79:5; 89:47 [EVV 89:46]; 94:3 etc.), while the list of evils (violence, iniquity, strife, contention, injustice) is reminiscent of the lament psalms.

But what are these troubles (2) that Yahweh appears content to observe (3)? We read of 'destruction', 'violence' (hāmās), 'strife' and 'contention' being rife, with the result that the law (tōrah) is ineffective. No 'justice' (mispāt) is done, wicked people surround the righteous, 'so justice goes out perverted' (4). Who are these 'wicked'?-are they external foes or Judeans?-and who are the righteous? While many candidates have been proposed, ${ }^{2}$ the text of 1:4a points to internal Judean corruption and the breakdown of social life. ${ }^{3}$ It would hardly have been appropriate for a Judean prophet to have spoken about the law (torrah) having become ineffective, and justice (mišpāt) not being victorious if his country was being overrun by a foreign power. It is more likely that these words

2See P. Jöcken, Das Buch Habakuk: Darstellung der Geschichte seiner kritischen Erforschung mit einer eigenen Beurteilung (Köln-Bonn, Peter Hanstein 1977). 'See J.G. Harris, 'The Laments of Habakkuk's Prophecy', EQ 45 (1973) 219, esp. 22. 
point to a setting of internal corruption within the Judean society, the result of which was the oppression and dispossession of those who found themselves powerless to redress such wrongs, the 'righteous'. This would appear to be the force of the word hāmās), 'violence' in 1:2.

\section{c. Habakkuk 1:5-11}

The Lord's reply is couched in the form of a prophetic oracle. Habakkuk speaks as Yahweh's prophet, calling his people to look around at the nations but warning them that what they observe will indeed astonish them (5). They will see a strange work, namely the raising of the kaśdîm, a bitter and impetuous people who march through countries appropriating what is not theirs (6). In 1:7-11 we are given further details of the Lord's strange work. But who are the kaśdîm? Are these the Chaldeans, the historical Babylonians who shortly before 600 $\mathrm{BC}$ in the period of the collapse of the Assyrian empire were able to establish their rule over Mesopotamia, and in the situation of comparative impotence of Egypt were able to move into Syria-Palestine?

The classic problem with this identification is this: if we have in 1:2-4 the prophet's complaint about wrongdoing and now in 1:5-11 the assurance from Yahweh that the wrongdoing is to be punished through the Chaldean attack, how can the prophet now complain about these Chaldean acts? It was, of course, fairly general Hebrew prophetical doctrine that Yahweh used the great nations to effect his work of judging his own people (e.g. Am. 6:14; Ho. 8:14; Is. 10:5-15; Je. 5:14-19; 49:37; Ezk. 5:16; Joel 2:25 etc). If indeed 1:5-11 is seen as an answer to the problem raised in 1:2-4, then truly there is a further problem! But I suggest that Habakkuk was troubled both by Judean injustices and also Chaldean rapaciousness, and that he was not convinced that the latter could adequately be explained as having been occasioned by the former. That is, I am suggesting that Habakkuk was calling into question the Hebrew prophetical doctrine that Yahweh was using the Chaldeans as his agents.

At one time the word qādîmāh of 1:9 was thought to be a difficulty in identifying the kaśdîm in 1:6 with the Babylonians: its literal meaning 'eastwards, towards the east' seemed unsuitable to describe a westward advance of Babylonians upon Syria-Palestine. But it is now more widely 
accepted that qãdîmāh can bear the meaning 'forwards', 4 or even 'east wind', 5 and this allows us to accept the one historical datum point in the prophecy and understand that what is spoken of in 1:6 and 9 is the forward advance of the Babylonian army from the east. It is possible to be more precise than this: as a result of their victory at Carchemish in $605 \mathrm{BC}$ the Babylonians gained possession of Syria-Palestine. ${ }^{6}$ In 604 or 603 BC Jehoiakim, who reigned in Jerusalem from 609 to 598 BC, became the 'servant' (2 Ki. 24:1) of Nebuchadnezzar. This further allows us to understand that the internal Judean social ills spoken of in 1:2-4 were those perpetrated in Jehoiakim's reign. We read of Jehoiakim shedding much innocent blood (2 Ki. 24:4), while Jeremiah's words about him were caustic in the extreme (Je. 22:13-19; 26:1-23). Such would have given more than adequate grounds for the complaint in 1:2-4.7

It has been objected that whereas in 1:5 the Chaldeans are portrayed as newcomers to the people of Judah, later (especially in 1:12-17) they seem to be well known. 8 This led some scholars to suggest different dates of origin for the various parts of Habakkuk 1.9 But then, perhaps the historical details are to provide a life-setting for the working out of a theological problem-something of what might be called an 'historical sketch' to set the scene for the discussion of the theological problem. As Kirkpatrick observed so long ago, the book of Habakkuk 'is the fruit of religious reflection'.10

\section{d. Habakkuk 1:12-17}

This is a return to the lament form. Habakkuk, speaking again on behalf of his people, addresses Yahweh in prayer, and this,

${ }^{4}$ As argued long ago by W.G. Wade, The Books of Zephaniah, Nahum and Habakkuk (with G.G.V. Stonehouse), Westminster Commentaries, (London, Methuen 1929) 176. See also D.S. Dykes, Diversity and Unity in Habakkuk (Vanderbilt University PhD thesis 1976) 42.

5See, e.g. D.W. Baker, Nahum, Habakkuk and Zephaniah (Leicester, IVP 1988) 53-4.

6See 2 Ki. 24:7; Je. 46:2. See B. Oded in J.H. Hayes and J.M. Miller (eds.), Israelite and Judean History (London, SCM 1977) 469ff.

7See Ed. Nielsen, 'The Righteous and the Wicked in Habaqquq', ST 6 (1953) 54-78, esp. 58.

${ }^{8}$ See Jöcken, op. cit., 80.

${ }^{9}$ See, e.g. Wade, op. cit., 160.

${ }^{10}$ A.F. Kirkpatrick, The Doctrine of the Prophets (London, Macmillan 1901) 273. 
it may be suggested, is in the nature of the second part of his complaint. The first part concerned the internal corruption; now the second part deals with the wickedness exhibited by the Chaldeans. Yet we should regard these two parts as making up the totality of the prophet's complaint to the Lord. The heart of the second part of the complaint is in 1:13:

You, whose eyes are too pure to look at evil, and are not able to regard iniquity;

Why do you look on those who deal treacherously, and are silent when the wicked devours the one more righteous than himself?

Judeans spoken of in 1:2-4 may be wicked and thus be under judgment, yet those appointed to effect the judgment seem to be yet more wicked (15-17)! How can Yahweh, who by nature is antagonistic to all that is evil, have raised up and sent such wicked people? Must such brutality, with no mercy, be endured for ever (17)?

At this point we may take note of the fact that by 603 BC Judah must have suffered deeply at the hands of the rival powers of the ancient orient, having been something of a pawn in the respective quests for power by Assyrians, Egyptians and Babylonians. By $603 \mathrm{BC}$ Judah had spent close on a century and a half in the grip of these military imperialists. Isaiah, prophesying in the days of the Syro-Ephraimite war, some 130 years earlier than Habakkuk, might have been able to regard the Assyrians as agents of Yahweh's chastening judgment of his people (Is. 7:18-25; 8:5-8), and other prophets might have continued to see the judgmental hand of God at work in the advance of the foreign nations. Nevertheless, even Isaiah came to see that there were limitations to what Yahweh required of the Assyrians (Is. 10:8-11, 13-14). Thus it is more than understandable that by the beginning of the seventh century $\mathrm{BC}$ Habakkuk should cry out in anguish over these continuing plunderings of Judah by the nations, in particular in his own day by the Babylonians.

\section{e. Habakkuk 2:1-5}

Here is a further revelation from Yahweh, expressed in the form of a prophetic oracle. The prophet takes his stand upon 
his watchtower, ${ }^{11}$ yet ready-presumably on behalf of his people - to answer back to the response of the Lord (1). ${ }^{12}$ In the last line of verse $2-1^{\mathrm{e}}$ maan yaarûs qôre' bô-we must assume that the main verb of the sentence is yārûs and that the subject is an imaginary reader (participle, 'reading one'). Thus we may translate as RSV did,

... so he may run who reads it. ${ }^{13}$

The 'running' could be intended either to be in a physical sense or proceeding in the ways intended and willed by God.14 In all probability the vision made plain upon tablets (2) that facilitates this 'running' is contained in 2:4, words that do comprise the core of Habakkuk's message. 15

So we come to $2: 4$ with its first line,

hinnēh 'uppe lâ lō yāsên nâ napsô bô.

Wellhausen pointed out that in place of uppelâ a noun is required to which, in the first place, the two subsequent masculine singular pronoun suffixes can refer, and which, in the second place, will stand in contrast to saddiq in the following line.16 The most likely solution is that lō' yãš râ napšô bô be regarded as a relative clause which lacks an 'šer, but is to be treated as a substantive, and that upp lâ be emended to ulap. 17 As far as the latter is concerned this is transposing the radicals of 'uppela and deleting the $h$, while culap is regarded as the pusal perfect of Ip with the meaning 'to faint', an example of a

$11^{\prime}$. . of patient and expectant faith', says W.H. Brownlee, 'The Placarded Revelation of Habakkuk', JBL 82 (1963) 319-25, esp. 319.

12Retaining $M T^{\prime}$ 's reading 'āsî́b.

${ }^{13}$ Contra both NRSV and REB.

14J.M. Holt, 'So he may run who reads it', JBL 83 (1964) 298-302.

15 This is argued by a large number of commentators and exegetes. See Jöcken, op. cit., 520.

16J. Wellhausen, Die Kleinen Propheten (Berlin, de Gruyter 1963) 168.

17 Pace the excellent treatment by J.A. Emerton, 'The Textual and Linguistic Problems of Habakkuk II.4-5', JBL 28 (1977) 1-18, this is advocated by e.g., J. Trinquet, Habaquq, Abdias, Joël, La Sainte Bible, (Paris, Les Editions du Cerf 1959) 28; C.A. Keller (with R. Vuilleumier), Michée, Nahoum, Habacuc, Sophonie (CAT: Neuchâtel, Delachaux \& Niestlé 1971) 158; A. Deissler, Zwölf Propheten II: Obadia, Jona, Micha, Nahum, Habakuk, Die Neue Echter Bibel, (Würzburg, Echter 1984) 226, among others. 
perfectum confidentiae. ${ }^{18}$ We may then translate the line as RSV did,

Behold, he whose soul is not upright in him shall fail

which stands in satisfactory contrast to the following line,

but the righteous shall live by his faithfulness.

A little freely, but retaining this sense, REB translates:

The reckless will lack an assured future, while the righteous will live by being faithful.

Thus 2:4 speaks of doom and salvation. Those spoken about in the first half of the verse-unnamed as yet, but whose identity will be revealed-are under sentence of doom. Speaking in a collective sense of this group the text says that his soul, his personality, is not right, or 'upright', and such a person is not pleasing to God. With such an insecure, tenuous and transitory grip on life that person's fate is inevitably to fail or faint. The second part of the verse speaks of 'righteous' ones-those proved innocent of charge-who are in a satisfactory relationship with God. They, living in steadfastness, conscientiousness and faithfulness to Yahweh, will know health: they indeed will be enabled to live life to the full. Yet, as the prophet warns in $2: 3$, this promise to his suffering people will not result in immediate solutions to problems. Thus the crucial aspects of behaviour will be steadfastness and faithfulness.

With verse 5 we are presented with two further problems: how is the verse to be translated, and is it to be related to the verses that precede or those that follow? As far as translation is concerned it would seem that we must emend the yayin ('wine') to hōn ('wealth').19 This allows us to understand that the reference in the first line of verse 4 ('Behold, he whose soul

\footnotetext{
18See W. Gesenius, E. Kautzsch, A.E. Cowley, Hebrew Grammar (Oxford, OUP 1910) para 106n.

${ }^{19}$ To retain the reading 'wine' does demand rather special pleading and resorting to explanations that involve somewhat unconvincing symbolism. See, e.g., J. Koenig, 'Zum Verständnis von Habakuk 2:4-5', ZDMG Supplementa i (1969) 291-2; S. Schreiner, 'Erwägungen zum Text von Hab 2:4-5', ZAW 86 (1974) 538-42. Apart from this, as Emerton expresses the matter op. cit., 6,' . . it may be doubted whether addiction to the bottle was so characteristic of the Chaldean (or the Assyrian) that his downfall was likely to be attributed to it'.
} 
is not upright in him shall fail') is to the rapacious Chaldean and that the prophet's judgment upon him continues in verse 5:

Moreover, wealth is treacherous,

the haughty man will not abide.

His desire is as wide as Sheol,

for he, like death, is never satisfied.

He has gathered for himself all nations,

and has collected all peoples as his own.

Thus, in the second place, there is to be observed a connection between verses 4 and 5: the lack of righteousness of the one whose soul is not upright in him (4) lies in his greed and rapacity (5). There is also a connection between verse 5 and 2:6-19 in which in a series of 'woes' the judgment already hinted at in verses 4 and 5 is made explicit in the context of forthcoming events. Though it is perhaps preferable to consider verse 5 along with the verses that precede, it does also serve as a transition to 2:6-19.20

\section{f. Habakkuk 2:6-19}

In these verses, through a series of 'woes', is expressed the fate of an oppressor. As in many Old Testament occurrences of the cry hôy ('woe!') the person addressed is not named. It has been argued that the prophetical cry 'woe!' is not so much an announcement that punishment will come to the addressed, but rather that the coming disaster is already implied in the 'woe-oracle'. ${ }^{21}$ As regards the identity of the unnamed oppressor there are a number of possibilities. A minority has argued that they are unjust Judeans, ${ }^{22}$ the majority that they are Chaldeans and a few, Assyrians. And indeed, the Chaldeans seem the most likely possibility: those whose fate has already been expressed in the veiled word in 2:4-'Behold, he whose soul is not upright in him shall fail'-are now the subject of this series of 'woes'.

20For details see R.L. Smith, Micah-Malachi, Word Biblical Commentary, (Waco, Word Books 1984) $105 f$.

${ }^{21}$ See, e.g. H.W. Wolff, Amos the Prophet: The Man and His Background (Philadelphia, Fortress 1973) 19.

22See E. Otto, 'Die Stellung der Wehe-Worte in der Verkündigung des Propheten Habakuk', ZAW 89 (1977) 73-107. 


\section{g. Habakkuk 2:20}

This verse concludes the series of woes in 2:6-19 and anticipates chapter 3 . If chapter 3 is not original to the book then presumably 2:20 is the work of a redactor. But more of that later. In the Old Testament the expression 'Yahweh's holy temple' may refer either to a heavenly dwelling place or to the Jerusalem temple. Here it would seem that the former is intended, for in the theophany scene which follows Yahweh makes his appearance from beyond and afar.

\section{h. Habakkuk 3}

The fact that this prayer ( $t^{\mathrm{e}}$ pillah) opens with a new heading and has the forms, languages and directions we associate particularly with the psalmic literature has inevitably raised questions about its original relationship with chapters 1 and 2. Then the fact that the Habakkuk Commentary found in the ancient library of Qumran comments on Habakkuk 1 and 2 but not on chapter 3 was thought to add weight to the consideration that the psalm was not a part of Habakkuk's original prophecy.

But there are other considerations that point in the opposite direction. The Habakkuk commentators of Qumran simply may not have found the psalm of chapter 3 suitable for the type of treatment that concerned and interested them. ${ }^{23}$ Then there is the fact of similarities in language in the three chapters; indeed, all three are shot through with the languages of both prophecy and psalmody. ${ }^{24}$ Perhaps more significant is the fact that there is a continuity in the general theme and content of the three chapters: the theme of chapter 3 is the confident expectation that Yahweh will bring to an end the oppression of his people, over which the prophet has agonised in chapters 1 and 2. Chapter 3 may be regarded as the expres-

${ }^{23}$ See, e.g. R.L. Smith, op. cit., 95. Nielsen, op. cit., 54-78, pointed out that the mysterious but concrete allusions in ch. 1 and 2 lent themselves in a particular way to an existentialist interpretation at a later time in a way that was not possible with ch. 3 (58).

24P. Humbert, Problèmes du Livre D'Habacuc (Neuchâtel, Secrétariat de L'Université 1944) 247. O. Eissfeldt, The Old Testament: An Introduction (Oxford, Blackwell 1965) 421, noted points of contact of the vocabulary in the three chapters, in particular that the enemy is described as 'the godless' in 1:4, 13 and in 3:13. See also G. Fohrer, Introduction to the Old Testament (London, SPCK 1974) 453. 
sion of faith for which 2:2-5 has led the way. It is to be observed that 3:2 specifically links up with 2:2-5, and that chapter 3 provides the development and resolution of Habakkuk's struggle expressed in chapters 1 and 2.

Further, it is not satisfactory to make a too definite distinction between the 'prophecy' of chapters 1 and 2 and the 'psalm' of chapter 3. As we have seen, there is a good deal of chapters 1 and 2 in the psalmic lament style, and these various considerations enable us the more easily to accept that all three chapters of the book came from the same author.

Habakkuk 3 is titled a 'prayer' ( $t^{\mathrm{e}}$ pillah), a general term in the Old Testament for prayer, occurring frequently in the Psalms, but also in the books of Kings, in 2 Chronicles and elsewhere. The real content of the prayer is in verse 2 , the first part of which sets out the ground of the prayer:

Yahweh, I have heard a report of you, and your work, Yahweh, I fear.

Presumably the intended reference is to past acts of deliverance, in particular the 'exodus events'. On the grounds that this is what he has done in the past, the prophet prays that in his own day Yahweh will revive such works. 'In the midst of the years' is intended presumably in the sense 'in our own time' (so NRSV, but compare REB). When the prophet prays also, 'in wrath may you remember mercy', we assume that he is thinking of those wicked aggressors who at present surround his people.

In 3:3-15 we have a theophany account of the type where the Lord appears as a divine warrior to assist his suffering people and to save them (8-15). The first part of the theophany scene (3-7) stresses Yahweh's omnipotence; not only are nations made to tremble, but also mountains and hills are shaken (6). Cushanites and Midianites, peoples of the south, would be some of the first to experience this mighty epiphany (7).

The theophany, or epiphany, motif 25 is found in a number of places in the Old Testament (e.g. Jdg. 5; Dt. 33: Is. 30;

25C. Westermann The Praise of God in the Psalms (Edinburgh, T. \& T. Clark 1981) would have us employ the word 'theophany' when God reveals himself and communicates to people through a mediator (as in Ex. 19 and 34) but 'epiphany' when he appears to aid his people (as in Jdg. 5). With others, I use the general term 'theophany' for Yahweh's 'helping 
59; 63 etc.), in particular in some psalms, usually thanksgiving hymns. ${ }^{26}$ It is usually associated with what Fretheim calls watershed moments in the lives of individuals or communities. ${ }^{27}$ The Lord appears from afar, and frequently there is a thunderstorm. Perhaps there are origins in the Canaanite tradition of the storm-god Baal, but usually there are Israelite roots too, such as the holy war tradition as in Judges 5 , or the exodus event as in Habakkuk 3.

The purpose of the powerful display of divine energy manifested in the Habakkuk 3 theophany emerges in verses 815: it is against the forces of evil, in verse 8 represented by the waters. The righteous fury (zasm) is against 'the head from the house of the wicked', which presumably we are to understand as being a reference to the Chaldean. Thus Yahweh-far from ignoring wrongdoing (1:2-4) or allowing corruption to go unpunished (1:12-17) - comes to save (yš) his people, that is, rescue them from their present evil plight, deliver them from their present imprisoning circumstances (13a):

You went out for the salvation of your people,

for the salvation of your anointed.

The reference to 'your anointed' ( $\mathrm{m}^{\mathrm{e}} \mathrm{si} i \mathrm{~h} e k \overline{\text { }}$ ) would seem to be to Yahweh's people in general, his anointed people as that expression is used in Psalms 28:8; 84:10 (EVV 9); 89:39, 52 (EVV 38,51 ), rather than to the king (as in La. 4:20).28 At any rate, as Watts says, 'God's entire power is committed to the battle against the oppressor, God's goal is salvation for his people'.29

The final verses of the book, 3:17-19, seem to presuppose conditions of scarcity rather than of military domination, one factor among others that has led some to regard them as not coming from the author of the rest of the book. ${ }^{30}$ But such a

interventions'. See A.H.W. Curtis's article 'Theophany' in R.J. Coggins and J.L. Houlden, op. cit., 694f.

${ }^{26}$ Westermann, op. cit., 93-101.

27T.E. Fretheim, The Suffering of God, Overtures to Biblical Theology, (Philadelphia, Fortress 1984) 80.

${ }^{28}$ See Jöcken, op. cit., 521f; W. Rudolph, Micha, Nahum, Habakuk, Zephania, KAT, (Gütersloh, Gerd Mohn 1975) $245 f$.

29J.D.W. Watts, The Books of Joel, Obadiah, Jonah, Nahum, Habakkuk and Zephania, NCBC, (Cambridge, CUP 1975) $149 f$.

30So, e.g. K. Elliger, Das Buch der zwölf Kleinen Propheten II, ATD, (Göttingen, Vandenhoek \& Ruprecht 1982) 50, 54. 
decision may arise out of a too prosaic reading of the book. As a result of the vision of Yahweh's coming the prophet is filled with such confidence in God that he can now face up to the possibility of an even worse scenario-life without fruit, food, flocks and herds. Yet even in that extremity,

I will rejoice in the Lord,

I will joy in the God of my salvation. (18)

Carroll asserts that 'the internal tensions [of the book of Habakkuk] defeat coherent exegesis', ${ }^{31}$ but the foregoing is intended to suggest that there is another possible assessment to make of the book. True there is a variety of forms employed in the book, but it is reasonable to argue that this is something more than 'a ragbag of traditional elements held together by vision and prayer. ..'32 We have seen how after the title in 1:1 we have a prayer lament in 1:2-4 which sets out the first part of the prophet's complaint on behalf of his people to God. After the Lord's reply in 1:5-11 couched in the form of a prophetic oracle, we have the second part of the prophet's complaint (1:12-17), again in the form of a prayer lament. Then there is a further revelation from Yahweh in 2:1-5 in the form of a prophetic oracle, following which is an extended word of judgment upon the oppressor, expressed in a series of prophetic 'woe' oracles (2:6-19). After the concluding and anticipatory word in 2:20, we have in chapter 3 the resolution of the prophet's theological problem in prayer, theophany psalm and expression of confidence. What may appear to be 'a ragbag of traditional elements held together by vision and prayer' (Carroll) is seen to have a satisfying overall shape and logic about it. Certainly there is a definite progression of mood from despair to joy, 33 from the statement of a theological problem to a satisfying resolution. As far as the employment of various forms is concerned, it is clear that prayers of lament, prophetic oracles, 'woe' oracles and the theophany psalm are all used in purposeful and appropriate ways. This would appear to be no haphazard use of a series of literary styles and forms; rather it is one in which each is employed in a judicious

31R.P. Carroll, op. cit., 269.

32Ibid.

33See D.S. Dykes, op. cit., 139. 
way, the result of which is to achieve a definite and particular effect.

\section{Eclecticism and Tradition}

If a series of literary forms-such as those particularly associated with prayers, prophetical and woe oracles, theophany psalms-were available, why should they not be used? So perhaps the author of the book of Habakkuk might have argued. But as well as taking up these various literary forms we also observe in this book another series of 'borrowings': in particular that the author expressed himself, to at least some degree, in the languages of the wisdom and Isaiah of Jerusalem traditions.

\section{a. Wisdom Terminology}

It has been pointed out to us that in the book of Habakkuk we have wisdom terminology, ${ }^{34}$ though the supposed wisdom 'influence' upon Habakkuk may have been somewhat overrated. There are, in fact, two words employed, once each, in Habakkuk that elsewhere in the Old Testament occur predominantly in the wisdom writings. First there is tok a hat ('complaint', 2:1). Otherwise this word is found 19 times in the wisdom writings (incl. Ps. 73) but only four times in other parts of the Old Testament. Thus, this word is not confined exclusively to the intellectual tradition,, 35 but we may say that its predominant usage is in the wisdom writings. Second, there is mādôn ('contention', 1:3) apart from this it occurs 15 times in Proverbs but only twice elsewhere (Ps. 80:6; Je. 15:10). Thus its usage too is predominantly in the wisdom writings. Then there are two words employed in Habakkuk that elsewhere in the Old Testament occur most frequently, but not predominantly, in wisdom writings. The first is amal ('iniquity', 1:3, 13), which elsewhere is to be found 33 times in wisdom writings and 18 in other books. The second is a combination of words, răsā' plus șaddiq ('evildoer' plus 'righteous', 1:4, 13), which otherwise occurs 78 times in wisdom literature and 25 times elsewhere. ${ }^{36}$

${ }^{34}$ D.E. Gowan, 'Habakkuk and Wisdom', Perspective IX (1968) 157-66; G.A. Tuttle, 'Wisdom and Habakkuk', StBibT 3 (1973) 3-14.

${ }^{35}$ R.N. Whybray, The Intellectual Tradition in the Old Testament (Berlin, de Gruyter 1974) 140.

${ }^{36}$ Gowan, op. cit., cites other words as evidence of wisdom influence on Habakkuk (cāmal plus rāc mādôn plus rîb, yāhîr, melîșah, hôkîah, mā̌sāl, 
Other aspects of the book of Habakkuk, as Gowan has pointed out, do remind us of the wisdom writings. The theodicy theme is a subject rarely handled in the Old Testament prophetic literature, but rather in Psalms, Job and Qoheleth. The same may be said about the style of the book, the dialogue between a human and God, and also about the structure which reminds us of the book of Job: both books begin with a complaint and end with a theophany.

\section{b. Habakkuk and Isaiah of Jerusalem ${ }^{37}$}

There are significant parallels here to be noted. First, there are two actions: Habakkuk takes his stand on his watchtower (2:1) which is reminiscent of the incident in Isaiah 21:8. Second, there are the similar actions-both involving 'waiting' - over the recording of oracles (2:2-3 and Is. 8:4; also Is. 30:8). Then there is the common employment of the concept of Yahweh's 'work' (Hab. 1:5; Is. 5:12). Further, though granted that this is a fairly general prophetical doctrine, there are striking similarities in the thought of Isaiah and Habakkuk over Yahweh's use of the great nations as his agents of judgment (Is. 7:20; 10:5f; Hab. 1:12). Moreover, with both there is to be observed a change in their thought: Isaiah at a later stage in his ministry came to see that the Assyrian did not understand his calling (10:7f.), which is similar to Habakkuk's assessment of the Chaldeans (1:15-17). The idolatry of these nations is also similarly expressed in Habakkuk 1:11 and Isaiah 10:13. As Isaiah sees that Yahweh must himself break the Assyrian (Is. $10: 12 ; c f .14: 24-7)$, so also Habakkuk pronounces his five-fold woe over the Chaldean (2:6-19). More, the opening woe in Habakkuk 2:6 is reminiscent of Isaiah 14:4. Further, one of Habakkuk's woes is specifically against Chaldean plundering (2:6-8), and that is reminiscent of Isaiah's invective against the plundering and boasting of the Assyrian king (Is. 10:6-15). And, of course, Isaiah 11:9b with its,

...for the earth shall be full of the knowledge of the Lord as the waters cover the sea

hîdah), but I suggest that they hardly occur sufficiently predominantly in the wisdom writings for us to regard them specifically as examples of wisdom terminology.

37On this topic see also, J.G. Janzen, 'Habakkuk 2:2-4 in the Light of Recent Philological Advances', HTR 73 (1980) 53-78, esp. 72-8; B. Peckham, 'The Vision of Habakkuk', $C B Q 48$ (1986) 617-36. 
is found in a slightly longer form in Habakkuk 2:14:

For the earth shall be filled

with the knowledge of the glory of the Lord

as the waters cover the sea.

It is clear, then, that in the book of Habakkuk there is this marked aspect of eclecticism: ${ }^{38}$ more, we may say that eclecticism is part and parcel of this book and of the whole style and approach of its author. Not only do we observe the use of a wide range of literary forms and expressions to convey the book's 'burden', but we see also a series of borrowings from the wisdom tradition and from the oracles of Isaiah of Jerusalem. These two factors may, on the one hand, lead us to conclude that the final text of the book is the result of a large amount of redaction, or alternatively to suggest to us the work of one author who had something of a penchant for eclecticism. Yet we have noted that there is the unity of theme, along with a logical progression of thought in the book. More, there is the clear, purposeful and-above all-appropriate employment of a series of literary forms at particular stages in the argument of the book. Cumulatively, these factors incline us quite definitely to the latter possibility, namely, that we are reading the work of one author-whom we may continue, perhaps more confidently, to refer to as Habakkuk. Yet the most marked eclecticism of Habakkuk is to be observed in the employment of the language and thought forms of Isaiah of Jerusalem: the prophet takes up words, phrases and concepts which were used by Isaiah. This is not done in any slavish way, for the theme of divine judgment on Israel through a foreign nation is in fact questioned.

An earlier generation of Old Testament scholarship rendered us inestimable service in establishing that various parts of the complete Isaiah book of 66 chapters came from a series of widely separated historical settings. Now a more recent phase in Isaiah studies has alerted us to the fact that

${ }^{38}$ Over the years various other parallels between Habakkuk and other prophets have been noted: e.g. Hab. 2:15-16 and Je. 25:15-29; 51:7; La. 4:21; Ez. 23:31-3; also, Hab. 2:13b and Je. 51:58; also Hab. 2:18-19 and Je. 2:27ff; 10:1ff; 18:15; also, Hab. 2:12 and Mi. 3:10. These are not as pervasive and marked as those we have considered hitherto. As far as Jeremiah is concerned we are perhaps dealing with prophets who prophesied around the same time. 
these various parts of the Isaiah book do have themes in common and that throughout the book we should observe the development of a number of themes. ${ }^{39}$ We now realise that there is much more to the whole book than a mere joining end to end of a number of disparate sections that in sum neatly filled a scroll. Of course, while we may make such observations about the completed composition, we do have to say that we know next to nothing about the individuals or groups who over a long period of time were responsible for this handing-on and development of the tradition which had a recognisable starting point in the ministry of Isaiah of Jerusalem. 40

Yet Habakkuk may be seen to stand somewhere-in a way that is not possible to define too closely, for the reason that we know little of the process or the groups responsible for collecting and transmitting the material-in this tradition. This would account for the substantial borrowings from Isaiah and the development of Isaianic themes, both of which we see in Habakkuk. Of course, Habakkuk lived-so we have arguedsome 130 years later than that phase of Isaiah's ministry concerned with the Syro-Ephraimite war (to which the oracles in Is. 7 and 8 related), and we are therefore not surprised that the assessment of the divine role in the encroachments of the foreign nations is somewhat different in the recorded oracles of these two prophets. By Habakkuk's day his people had lived under the domination of foreign powers for well over a century, and Habakkuk could perhaps understandably see little of ultimate good for the people of Judah and Jerusalem as a result of that. Further, Habakkuk tended to see things from his people's point of view-and thus he employed the lament form for a part of his message-whereas Isaiah observed events more (as if) from Yahweh's viewpoint. While Isaiah prophesies as to what he sees Yahweh must do, Habakkuk asks questions on behalf of his people. In particular, Habakkuk asks 'how

${ }^{39}$ See, e.g. R.E. Clements, 'Beyond Tradition-History: Deutero-Isaianic Development of First Isaiah's Themes', JSOT 31 (1985) 95-113; C.A. Evans, 'On the Unity and Parallel Structures of Isaiah', VT 38 (1988) 129-47.

40Is. 8:16 can hardly be appealed to for evidence of such a long term activity. The reference there seems to have been to a need to record in writing oracles that related to a particular historical incident, for the principal reason that at the time their message was generally being ignored. See M.E.W. Thompson, Situation and Theology: Old Testament Interpretations of the Syro-Ephraimite War (Sheffield, Almond 1982) 37-40. 
long?' must Judah and her people be subjected to the cruel oppression of a foreign power.

Some fifty years or so later than Habakkuk's ministry an Israelite prophet would come before his people with a word of comfort and hope from the Lord. This prophet we are accustomed to call the Second Isaiah. $41 \mathrm{He}$ spoke to his people during their time in exile, but at a moment in history pregnant with hope for the exiles, thanks to the military victories of Cyrus the Persian. There are themes found both in Habakkuk and the Second Isaiah, along with a certain commonality of style and approach, which demand our attention.

That use of psalmic forms which we noted in Habakkuk is also to be seen in the prophecies of Second Isaiah (e.g. Is. 42:10-13; 44:23; 49:13). Both prophets speak of Yahweh coming to the aid of his people (Hab. 3; Is. 40:3-5): in Second Isaiah there is a definite emphasis on the fact that Yahweh is a redeeming God (41:14; 43:14; 44:6, 24; 47:4; 48:17; 49:7, 26; 54:5, 8). We read in Habakkuk 3 of the Lord's glory and its effect on those who witness it, and that theme also has significant emphasis in Second Isaiah (40:5; 41:20; 43:21). Both of these prophecies are concerned to interpret Israel's suffering. This is a major concern of Habakkuk, while Second Isaiah was clearly at some pains to assert that although Yahweh may have inflicted punishment upon his people there would be an end to their suffering, for Yahweh was in control of events (40:1-2; $50: 1 ; 43: 22-8)$ and had not forgotten his people (40:27-31). They both treat the role of the foreign kings, but not in the way that their prophetic predecessor had, namely, foreign domination as an inevitable consequence of their people's sin. Habakkuk questioned how God could use such a rapacious tyrant as the Chaldean for his purposes (1:12-17), while Second Isaiah saw that Cyrus the Persian would be used by Yahweh to restore Israel to her own land (44:24-45:7). They both deal-as Isaiah of Jerusalem had done earlier-with the theme of idol worship (Is. 2:8; 10:13; Hab. 2:18-19; Is. 40:19-20; 41:6-7 [Is. 44:9-20 is probably not the work of Second Isaiah]). Further, both Habakkuk

41The 'fifty years' in the preceding sentence is both approximate and tentative. Perhaps we might date the ministry of Habakkuk around 595 $\mathrm{BC}$ and that of the Second Isaiah around $540 \mathrm{BC}$. On the latter see, e.g. R.N. Whybray, The Second Isaiah, Old Testament Guides, (Sheffield, JSOT 1983) 12. 
and Second Isaiah assume two roles. On the one hand both were Yahweh's messengers. On the other hand, while Habakkuk cried out to Yahweh on behalf of his people (1:12-17) and was yet ready to challenge Yahweh further (2:1-5), Second Isaiah was something of a persuader who sought to convince his people that he truly did have a message from the Lord for them. 42 And both of their prophecies end with a picture drawn from the world of nature (Hab. 3:17-19; Is. 55:12-13).

These considerations only serve to reinforce our earlier conclusions that Habakkuk stood in some way in the Isaiah tradition. In that stream of prophetic life of which we have literary evidence stretching from Isaiah of Jerusalem to Second Isaiah, and even beyond to the Third Isaiah, there is Habakkuk who drew upon the message of Isaiah, interpreting it afresh for his own day, and in one major aspect of it asking questions as to its continuing appropriateness. Yet in Habakkuk there is also that element of anticipation of what was yet to come in the prophecies of Second Isaiah, themselves those joyful and confident prophetic words that mark the burgeoning for a new age of the Isaian prophetic tradition. No doubt there were others who were concerned to pass on, interpret and reinterpret the Isaiah message for their own days-dare we call them disciples?-whose oracles have not been preserved. It is becoming increasingly clear to us that such an interpretive and transmitting process was taking place: perhaps we may say that through the preserved oracles of Habakkuk we are given a small glimpse into that process.

\section{Theodicy and Prayer}

While individually the oracles, laments and psalmic genres found in the book of Habakkuk are known to us in other parts of the Old Testament, the combination and arrangement of them into one work makes the Habakkuk book unique. With the employment of laments and a psalm in such a significant way Habakkuk is something of the 'maverick' prophecy in the Old Testament. Yet, as we have argued, this book would seem-with a possible few exceptions-to be the work of one

42Whybray, Ibid., 15-18. 
person,, 3 and thus we may with our renewed sense of confidence continue to refer to its author as Habakkuk. This Habakkuk was, according to the written traditions we have received, among the prophets. The marked cultic aspect of the book has led some scholars to suggest that Habakkuk was a cultic prophet, but given the evidence at our disposal that is speculative. 44 Others have argued that the book was a cultliturgy, ${ }^{45}$ others that it is an imitation of one. ${ }^{46}$ These again, inevitably, are speculations. ${ }^{47}$ The same goes for the question whether the psalm of Habakkuk 3 was ever employed in a cultic setting, or even, that it was used in an Israelite festival.48

Yet-I believe that we can say something by way of explanation about the considerable amount of literature in the book that appears to bear the hallmarks of cultic material, and in particular about the fact that a new title stands at the beginning of chapter 3 , the crucial word of which is $t^{\mathrm{e}}$ pillah, 'prayer, psalm'. The employment of psalmic lament forms in chapters 1 and 2 may perhaps prepare us for the theophany psalm in chapter 3, but the new title with its 'psalm [or 'prayer'] of Habakkuk' suggests to us an emphasis upon the fact that a particular form is deliberately being employed at this stage in the work.

May one not suggest that what is being signified here is that the only answers Habakkuk is able to give in response to his people's desperate sufferings are to be expressed in cultic terms, in the language of worship? Reference has already been made to Psalm 73 with its similar theme to that of the book of Habakkuk. The psalmist is deeply perplexed over questions as

${ }^{43} \mathrm{~B}$. Peckham, op. cit., 617-36, argues that the book of Habakkuk is a unified composition. His explanation of this unity is very different from that which is suggested here.

${ }^{44}$ P. Jöcken, 'War Habakuk ein Kultprophet', in H.J. Fabry (ed.), Bausteine biblische Theologie. Festgabe für G. Johannes Botterweck zum 60. Geburtstag dargebracht von seinen Schülern, Bonner Biblische Beiträge 50, (Bonn, Peter Hanstein 1977) 319-32.

${ }^{45}$ E.g. Nielsen, op. cit., 290-6.

${ }^{46}$ E.g. G. Fohrer, Introduction to the Old Testament (London, SPCK 1970) 453.

47See Jöcken, Das Buch Habakuk, 416-25, 436-46, 451-81, 505-8 for detailed consideration and critique.

${ }^{48}$ The last mentioned is argued by J.H. Eaton, 'The Origin and Meaning of Habakkuk 3', ZAW 76 (1964) 144-71, esp. 160ff; Watts, op. cit., 144. 
to the sufferings of those who appear to be righteous, yet has failed to come to a satisfying intellectual solution to the problem (Ps. 73:16). But the great turning moment in that psalm comes in verse 17 when the psalmist 'went into the sanctuary of God': in the setting of worship, in 'the place of the nearness of God', 49 there came to him a new realisation that he was held in Yahweh's care, and thus he came to a sense of peace. So in Habakkuk 3 we are intended to understand that we are in the milieu of worship, in those realms in which Yahweh's devotees 'see things differently', where they gain some further insights into the total scheme of things. Habakkuk's resolution of his problem comes when he is able to believe that the Lord is present with him and his people, although they may at present find themselves beset with deep problems of life. Indeed, we may question how could such a belief be expressed other than in such language as Habakkuk employs, namely the language of Yahweh's theophany which asserts that the Lord is present on earth, and more, that he does act for the salvation of his people.

The parallel with Job presents itself: argumentation and the propounding of doctrine, however sound, as articulated by Job's friends fails to satisfy the sufferer. Satisfaction and peace come through the revelation of Yahweh in the speeches of the Lord (Job 38:1-40:2; 40:6-41:34). Indeed, what those speeches of the Lord in the book of Job do, and what also Habakkuk 3 does, is to take us to the heart of religion, that trembling awe before the unfathomable mystery of God, his being and his ways, but who, his devotees believe, is yet ready to speak to an individual, and whose will is salvation for his people, who wills life for those who owe their creation to him.

The book of Habakkuk is about life-life which the prophet sees cannot be known and enjoyed either by those who deal corruptly, or by those who oppress others. Their doom is already sealed. Yet the righteous will live by their faithfulness and steadfastness, and to them Yahweh's vindication-which cannot adequately be expressed apart from in terms of the language of worship and cult-will eventually be known. In that day it will be made plain to them that Yahweh in his saving presence is with them. Thereby will they be given

${ }^{49}$ H.-J. Kraus, Psalms 60-150: A Commentary (Minneapolis, Augsburg 1989) 89. 
strength for even greater and more fundamental problems and sufferings. That at least is the experience to which Habakkuk himself comes. It may be significant that whereas earlier Habakkuk has spoken on behalf of his people, his closing expression of confidence is personal, expressed in the singular, 'yet I will rejoice in the Lord. ..' (3:17-19).

The subject matter of the book of Habakkuk is theodicy: how can Yahweh, he who is just, allow sufferings to continue to afflict his righteous people? Yet here there is no intellectual solution, any more than there is in Psalm 73 or the book of Job or elsewhere. Nevertheless Habakkuk, like Job, can continue to pray to Yahweh in the reality of a relationship with God.50

It is surely significant that so much of the book of Habakkuk is expressed in the terms and language of prayer. In a prayer of lament the book opens (1:2-4), and soon will continue with another (1:12-17), while the whole of the third chapter is entitled 'a prayer' ( $t^{e}$ pillah). That is, no less than half of the verses of the whole book go into these three prayers. While prophetic oracles, woe oracles and the prayers each have their purposeful part in the development of the argument of the book, both Habakkuk's complaints to Yahweh and any expression of faith that he is able to contribute towards his people's peace are expressed in the language of prayer. It is as if for this prophet the prophetical and woe oracles serve a somewhat subservient function to those prayers that are employed to express what are the most significant parts of the prophet's burden. Habakkuk is indeed the Old Testament's maverick prophecy!

${ }^{50}$ C.S. Rodd, The Book of Job, Epworth Commentaries, (London, Epworth 1990) 105-13, emphasises the point that Job, but not one of his friends, continues to pray to God. 